Vol 11, Issue 12, 2018

\title{
COMPARISON WITH INTENSITY OF SECONDARY DENGUE INFECTION BY DETECTING DENGUE-SPECIFIC IMMUNOGLOBULIN G ANTIBODIES
}

\author{
SUDIPTA PODDAR*, AMIYA KUMAR HATI \\ Department of Medical Physiology, Lincoln University College, Petaling Jaya 47301, Malaysia. \\ Email: drsudiptapoddar@gmail.com
}

Received: 12 May 2018, Revised and Accepted: 10 August 2018

\begin{abstract}
Objective: Detection of dengue-specific immunoglobulin G (IgG) antibodies in the serum of healthy individuals signifies previous dengue infection. This phenomenon can be utilized to demonstrate dengue activity in a suspected area and to stratify intensity of infection in the urban and rural surroundings.

Methods: Serum samples of altogether 881 healthy volunteers, 560 persons living in the central part of the city Kolkata and 321 individuals residing at a village Memari (highly endemic for dengue), $85 \mathrm{Km}$ away from Kolkata, having no apparent proof of dengue activity were examined for the detection of dengue-specific IgG antibodies.

Results: Of 560 serum samples collected from Kolkata, 55.5\% (249) were IgG reactive. Respective figures for Memari were 321 and 25.3\% (81). This indicated that the virus was also active at rural area, though the endemic property was lower than in Kolkata. In both urban ( $\mathrm{r}=-0.585$, $\mathrm{p}=0.017$ ) and rural $(r=-0.392, p=0.013$ ) West Bengal, the suspected and IgG reactive cases apparently negatively correlated with age, but the percentage of reactivity was found to increase with age. The number of IgG reactive cases was significantly more in Kolkata than at Memari, indicating that dengue virus was active at Memari though the endemic property was much lower than that of Kolkata and chances of secondary dengue infection vis-a-vis dengue hemorrhagic fever would be more in Kolkata than at Memari.
\end{abstract}

Conclusion: Evaluation of IgG specific dengue antibodies can be utilized to compare intensity of secondary dengue infection vis-a-vis DHF and its endemic property in different places, furnish a preliminary idea.

Keywords: Dengue, Endemic, Immunoglobulin G antibodies, Kolkata, Serological surveillance, Percentage of reactivity, Secondary dengue.

(C) 2018 The Authors. Published by Innovare Academic Sciences Pvt Ltd. This is an open access article under the CC BY license (http://creativecommons. org/licenses/by/4. 0/) DOI: http://dx.doi.org/10.22159/ajpcr.2018.v11i12.27276

\section{INTRODUCTION}

According to the World Health Organization, antidengue serum immunoglobulin G (IgG) antibodies are generally detectable at low titers at the end of the work of illness, increase, thereafter, remain detectable after several months, and possibly even for the life [1]. Dengue-specific IgG antibodies are not detected in those persons who have never suffered from dengue infection. The presence of denguespecific IgG antibodies in a healthy individual indicates previous or old dengue infection.

Although dengue is essentially an urban malady, it is spreading widely and steadily in rural India [2-4]. In 2005, an epidemic outbreak of dengue affected 10 of 18 districts in the state of West Bengal, India, with altogether 19 deaths [5]. In 2012, another major dengue outbreak again occurred in several districts of the state, including Kolkata [6].

A study shows the use of Acalypha indica leaf extract to control dengue vector [7]. Potential role of Carica papaya and its active constituents are also observed in the prevention and treatment of dengue fever and other various diseases [8]. Dengue shock syndrome (DSS) patients were distinguished by frequent complaint of abdominal pain, hepatomegaly, elevated hematocrit, and serum aspartate transaminase levels relative to non-DSS cases. Regular serum liver enzyme monitoring is suggested as worthwhile for predicting patients at greater risk of developing DSS [9].

The activity of dengue virus and its endemic properties in different areas can be monitored through demonstration of IgG antibodies in the healthy volunteers. To prove this hypothesis, two regions have been selected; one is an area in central Kolkata where dengue is highly endemic and the others are a village Memari where from apparently no activity of dengue virus has been reported. Healthy volunteers of these two places have been examined for the presence of denguespecific IgG.

\section{METHODS}

The study period extended from June to December 2013. The serum of 560 and 321 healthy volunteers having no fever from Central Kolkata (highly endemic for dengue) and the others a village Memari, $85 \mathrm{Km}$ from Kolkata (where from no activity of dengue virus was reported), respectively, were collected. The serum samples of 560 and 321 healthy volunteers from Kolkata and Memari, respectively, were tested in the Gautam Laboratories (i.e. National Accredited Biological Laboratory) for the presence or absence of dengue-specific IgG antibodies the ELISA test was performed using BioRad Kits [7]. The instructions of the manufacturer were minutely followed. Interpretation of ELISA results was made according to instructions, i.e., $<0.9$ as "no detectable antibody to dengue virus IgG," $0.9-1.1$ as "borderline positive," and >1.1 as "detectable antibody to dengue virus IgG."

Data analysis was performed using Statistical Package for the Social Sciences (SPSS) 21.0 (SPSS Inc., Chicago, USA). Calculation of correlation coefficients and regression analysis was used to determine the association of age with dengue positivity in the studied region. Results were mentioned as statistically significant when $p$ values were found to be $<0.05$.

This study was approved by the ethical committee of the organization (i.e.,the Gautam Laboratories, Kolkata). 


\section{RESULTS}

The sera of 311 (55.5\%) of 560 healthy volunteers residing in Kolkata were IgG reactive. Of 321 healthy persons living at Memari, 81 (25.2\%) were IgG reactive. Of a total of $881(560+321)$ individuals in this study, $392(311+81)$, i.e., $44.5 \%$ were IgG reactive. Among 560 residents of Kolkata, in the age groups of 0-20 years, 21-40 years, $41-60$ years, and 61-80 years, respectively, in 51.5\% (340), 56.2\% (137), 67.7\% (65), and $18.3 \%$ (18) of individuals' dengue-specific IgM antibodies were detected, respectively (Table 1)
Dengue reactive IgG antibodies were detected of 321 persons living at Memari, in the age groups of 0-20 years, 21-40 years, 41-60 years, and 61-80 years, respectively, in $20.8 \%$ (236), 31.7\% (54), 44.4\% (27), and $75 \%$ (4) were dengue-specific IgG reactive (found to possess denguespecific IgG antibodies) (Table 2).

Correlation between age group and IgG reactive cases of dengue in Kolkata and Memari

Both IgG reactive cases of Kolkata ( $\mathrm{r}=0.585 ; \mathrm{p}=0.017)$ and Memari $(r=0.392 ; p=0.132)$ showed a moderate negative correlation with age

Table 1: IgG reactive cases in healthy volunteers of Kolkata

\begin{tabular}{|c|c|c|c|c|c|c|c|c|c|}
\hline $\begin{array}{l}\text { Age } \\
\text { groups }\end{array}$ & $\begin{array}{l}\text { Total } \\
\text { number of } \\
\text { patients }\end{array}$ & $\begin{array}{l}\text { Number } \\
\text { of male } \\
\text { patients }\end{array}$ & $\begin{array}{l}\text { Number } \\
\text { of female } \\
\text { patients }\end{array}$ & $\begin{array}{l}\text { IgG } \\
\text { reactive }\end{array}$ & $\begin{array}{l}\text { IgG } \\
\text { non-reactive }\end{array}$ & $\begin{array}{l}\% \text { of } \\
\text { reactivity }\end{array}$ & $\begin{array}{l}\% \text { of } \\
\text { non-reactivity }\end{array}$ & $\begin{array}{l}\% \text { of } \\
\text { reactivity } \\
\text { among the } \\
\text { age groups }\end{array}$ & $\begin{array}{l}\% \text { of } \\
\text { non-reactivity } \\
\text { among the age } \\
\text { groups }\end{array}$ \\
\hline $0-5$ & 55 & 35 & 20 & 11 & 44 & 20 & 80 & 51.5 & 48.5 \\
\hline $6-10$ & 58 & 31 & 27 & 26 & 32 & 44.8 & 55.2 & & \\
\hline $11-15$ & 89 & 55 & 34 & 48 & 41 & 54 & 46 & & \\
\hline $16-20$ & 138 & 93 & 45 & 90 & 48 & 65.2 & 34.8 & & \\
\hline $21-25$ & 38 & 26 & 12 & 22 & 16 & 57.9 & 42.1 & 56.2 & 43.8 \\
\hline $26-30$ & 43 & 23 & 20 & 25 & 18 & 58.1 & 41.9 & & \\
\hline $31-35$ & 27 & 11 & 16 & 14 & 13 & 51.9 & 48.1 & & \\
\hline $36-40$ & 29 & 14 & 15 & 16 & 13 & 55.2 & 44.8 & & \\
\hline Total & 137 & - & - & 77 & 60 & - & - & & \\
\hline $41-45$ & 16 & 11 & 5 & 9 & 7 & 56.3 & 43.7 & 67.7 & 32.3 \\
\hline $46-50$ & 24 & 13 & 11 & 15 & 9 & 62.5 & 37.5 & & \\
\hline 51-55 & 14 & 8 & 6 & 11 & 3 & 78.6 & 21.4 & & \\
\hline Total & 65 & - & - & 44 & 21 & - & - & & \\
\hline $61-65$ & 10 & 9 & 1 & 9 & 1 & 90 & 10 & 83.3 & 16.7 \\
\hline $66-70$ & 3 & 3 & 0 & 1 & 2 & 33.3 & 66.7 & & \\
\hline $71-75$ & 4 & 2 & 2 & 4 & 0 & 100 & 0 & & \\
\hline $76-80$ & 1 & 1 & 0 & 1 & 0 & 100 & 0 & & \\
\hline Total & 18 & - & - & 15 & 3 & - & - & & \\
\hline $\begin{array}{l}\text { Grand } \\
\text { total }\end{array}$ & 560 & 343 & 217 & 311 & 249 & 55.5 & 44.5 & & \\
\hline
\end{tabular}

Table 2: IgG reactive cases in healthy volunteers of Memari

\begin{tabular}{|c|c|c|c|c|c|c|c|c|c|}
\hline $\begin{array}{l}\text { Age } \\
\text { groups }\end{array}$ & $\begin{array}{l}\text { Total } \\
\text { number of } \\
\text { patients }\end{array}$ & $\begin{array}{l}\text { Number } \\
\text { of male } \\
\text { patients }\end{array}$ & $\begin{array}{l}\text { Number } \\
\text { of female } \\
\text { patients }\end{array}$ & $\begin{array}{l}\text { IgG } \\
\text { reactive }\end{array}$ & $\begin{array}{l}\text { IgG } \\
\text { non- reactive }\end{array}$ & $\begin{array}{l}\% \text { of } \\
\text { reactivity }\end{array}$ & $\begin{array}{l}\% \text { of } \\
\text { non-reactivity }\end{array}$ & $\begin{array}{l}\% \text { of } \\
\text { reactivity } \\
\text { among the } \\
\text { age groups }\end{array}$ & $\begin{array}{l}\% \text { of } \\
\text { non-reactivity } \\
\text { among the } \\
\text { groups }\end{array}$ \\
\hline $0-5$ & 3 & 2 & 1 & 0 & 3 & 0 & 100 & 20.8 & 79.2 \\
\hline $6-10$ & 35 & 14 & 21 & 9 & 26 & 25.7 & 74.3 & & \\
\hline $11-15$ & 47 & 20 & 27 & 4 & 43 & 8.5 & 91.5 & & \\
\hline $16-20$ & 151 & 62 & 89 & 36 & 115 & 23.8 & 76.2 & & \\
\hline Total & 236 & - & - & 49 & 187 & - & - & & \\
\hline $21-25$ & 12 & 7 & 5 & 4 & 8 & 33.3 & 66.7 & 31.5 & 69.5 \\
\hline $26-30$ & 15 & 4 & 11 & 3 & 12 & 20 & 80 & & \\
\hline $31-35$ & 13 & 8 & 5 & 5 & 8 & 38.5 & 61.5 & & \\
\hline $36-40$ & 14 & 6 & 8 & 5 & 9 & 35.7 & 64.3 & & \\
\hline Total & 54 & - & - & 17 & 37 & - & - & & \\
\hline $41-45$ & 10 & 7 & 3 & 4 & 6 & 40 & 60 & 44.4 & 55.6 \\
\hline $46-50$ & 12 & 3 & 9 & 8 & 4 & 66.7 & 33.3 & & \\
\hline 51-55 & 1 & 0 & 1 & 0 & 1 & 0 & 100 & & \\
\hline $56-60$ & 4 & 2 & 2 & 0 & 4 & 0 & 100 & & \\
\hline Total & 27 & - & - & 12 & 15 & - & - & & \\
\hline $61-65$ & 2 & 1 & 1 & 2 & 0 & 100 & 0 & 75 & 25 \\
\hline $66-70$ & 0 & 0 & 0 & 0 & 0 & 0 & 0 & & \\
\hline $71-75$ & 2 & 2 & 0 & 1 & 1 & 50 & 50 & & \\
\hline $76-80$ & 0 & 0 & 0 & 0 & 0 & 0 & 0 & & \\
\hline Total & 4 & - & - & 3 & 1 & - & - & & \\
\hline $\begin{array}{l}\text { Grand } \\
\text { total }\end{array}$ & 321 & 138 & 183 & 81 & 240 & 25.2 & 74.8 & & \\
\hline
\end{tabular}


group. The data of Kolkata are statistically significant $(\mathrm{p}<0.05)$, whereas data of Memari are not.

Both total and IgG reactive cases of Kolkata $(r=0.585 ; \mathrm{p}=0.017)$ and Memari ( $\mathrm{r}=0.392$; $\mathrm{p}=0.013$ ) showed a negative correlation with age, but the percentage of reactivity was found to increase with age (Fig. 1).

\section{DISCUSSION}

The results clearly indicated the activity of dengue virus in a rural surrounding, where dengue-specific IgG antibodies were found in $25.3 \%$ of the healthy volunteers, which figure was $55.5 \%$ in the city of Kolkata. In case the arrivals of a new serotype of dengue virus, the chance of occurrence of secondary dengue cases would be more in Kolkata than at Memari (Figs. 2 and 3).

IgG reactive cases were found in almost all the age groups and as the age advanced, the percent positivity of IgG reactive cases increased both in Kolkata and at Memari (Fig. 1). This pattern was more significant in Kolkata than that of Memari, i.e., all the age groups were more vulnerable to secondary infection in Kolkata, than at Memari. Again, along with the advancement of the age, the risk of infection would increase (Fig. 1). This pattern of distribution of old dengue cases pointed out that secondary dengue cases would be distributed in all the age groups in both the areas that tallied with a previous study [4].

As Kolkata was more endemic than Memari for dengue, the chance of occurrence of dengue infection and dengue hemorrhagic fever (DHF) would be more in Kolkata than at Memari.

Area wise presence or absence of dengue virus activity and stratification of the endemic property of dengue could be ascertained and compared through such simple cost-effective serological epidemiologic studies.

One previous study supported this hypothesis [5], where DHF cases were found in greater number in Kolkata than at the villages and in Kolkata, of all dengue cases (224) diagnosed serologically in that year of epidemic (2005), 65.6\% (147) of the patients were secondary dengue cases when dengue three serotypes were documented [5].

Through detection of dengue-specific IgG antibodies in the serum of the target population, some valuable epidemiological information could be obtained. High dengue IgG serological positivity (55.5\%) found in the population was an indication that dengue might be endemic in Kolkata for a long time into the future, which again confirmed dengue as an "urban disease" in West Bengal. Public awareness, proper vector control, and vigilant surveillance would be critical to keep the infection rates down and to prevent outbreaks.

\section{CONCLUSION}

The activity of dengue virus in an area can be evaluated through IgGspecific dengue antibodies in the healthy volunteers, and this simple method can be utilized to compare intensity of dengue infection and its endemic property in different places giving a preliminary first-hand idea of chance of occurrence of secondary dengue vis-a-vis DHF.

\section{ACKNOWLEDGMENTS}

The authors are thankful to Prof. Datuk Dr. Abdul Gani Bin Mohammed Din, Deputy Vice Chancellor (Academic), Lincoln University College and Prof. Dr. Amiya Bhaumik, CEO, and Vice Chancellor for giving necessary permission to proceed the work and also to the Directors of Gautam Laboratories Imaging and Research Centre, India, for various helps.

\section{AUTHORS' CONTRIBUTION}

Dr. Sudipta Poddar and Dr. Amiya Kumar Hati conceived of the presented idea. Dr. Sudipta performed the analysis and computations.

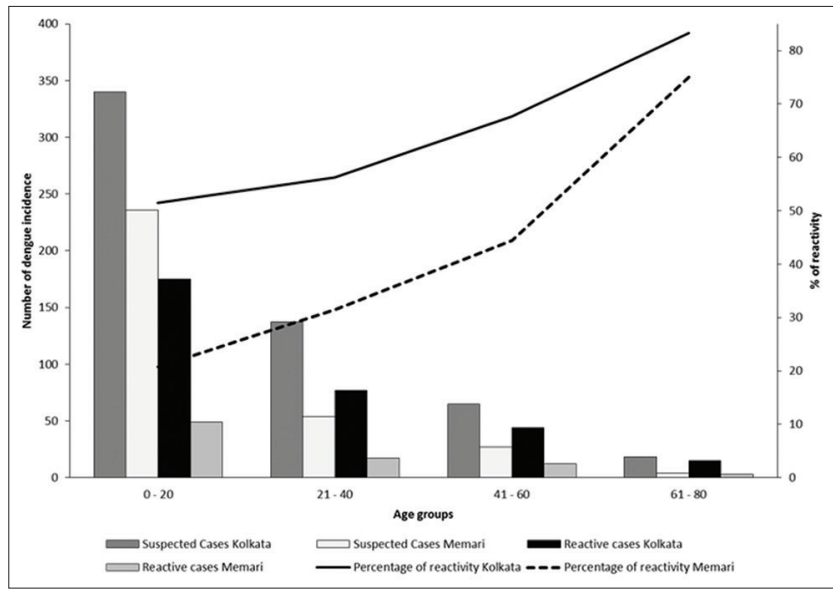

Fig. 1: Suspected, detected cases, and percentage of immunoglobulin $\mathrm{G}$ reactivity of dengue in different age groups reported in 2013

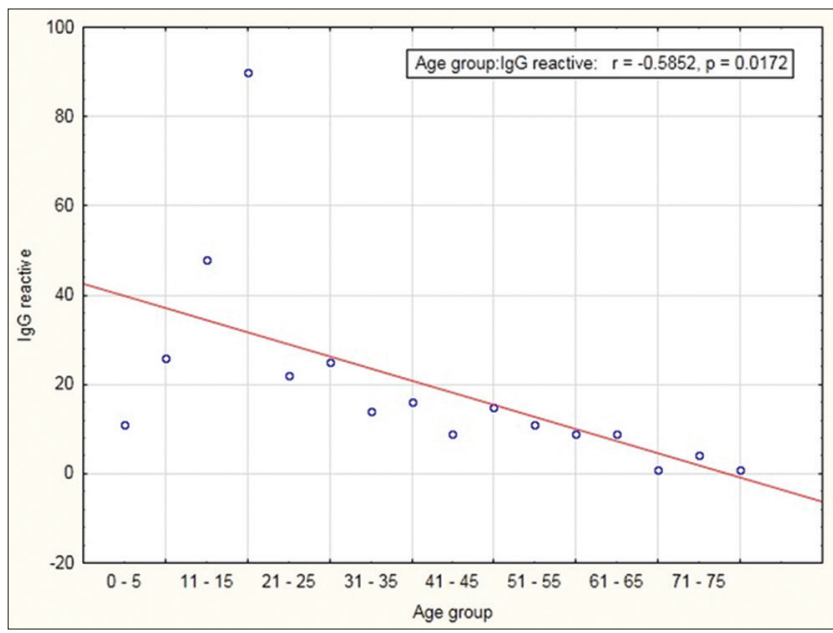

Fig. 2: Correlation between age group and immunoglobulin G reactive cases of dengue in Kolkata

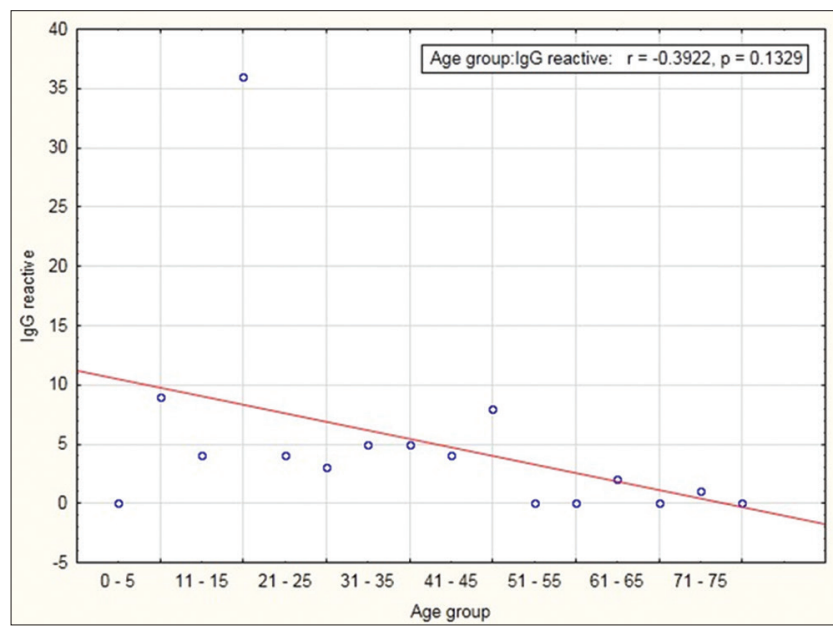

Fig. 3: Correlation between age group and immunoglobulin G reactive cases of dengue in Memari

Dr. Amiya verified the analytical methods and encouraged Dr. Sudipta to investigate and supervised the findings of this work. All authors discussed the results and contributed to the final manuscript. 


\section{CONFLICTS OF INTEREST}

The authors declare that they have no conflicts of interest.

\section{REFERENCES}

1. World Health Organisation. TDR Dengue Guideline for Diagnosis, Treatment, Prevention and Control. Geneva, Switzerland: World Health Organisation; 2009. p. 145.

2. Baruah K, Dhariwal AC. Epidemiology of dengue, its prevention and control in India. J Indian Med Assoc 2011;109:82-6.

3. Bhattacharyya N, Neogi DK, Hati AK. An outbreak of dengue in a remote area of West Bengal. Indian J Med Micobiol 1997;15:139-41.

4. Hati AK. Dengue serosurveillance in Kolkata, facing an epidemic in West Bengal, India. J Vector Borne Dis 2009;46:197-204.
5. Hati AK. Studies on dengue and dengue haemorrhagic fever (DHF) in West Bengal state, India. J Commun Dis 2006;38:124-9.

6. Majumdar R, Jana CK, Ghosh S, Biswas U. Clinical spectrum of dengue fever in a tertiary care centre with particular reference to atypical presentation in the 2012 outbreak in Kolkata. J Indian Med Assoc 2012;110:904-6.

7. Ashwini U, Taju G, Thirunavukkarasu P, Asha S. Pupal emergence inhibition activity of Acalypha indica leaf extract against dengue vector, Aedes albopictus mosquito. Int J Pharm Pharm Sci 2017;9:114-8.

8. Rahmani AH, Aldebasi YH. Potential role of Carica papaya and their active constituents in the prevention and treatment of diseases. Int $\mathrm{J}$ Pharm Pharm Sci 2017;8:11-5.

9. Mehta A, Pandit A. Liver dysfunction and dengue shock syndrome: A clinical and laboratory study of pediatric dengue patients. Innov $\mathrm{J}$ Med Sci 2017;5:1-2. 